\title{
Nihilisasi Peran Negara: Potret Perkawinan Samin Nirkonflik
}

\author{
Moh. Rosyid \\ Sekolah Tinggi Agama Islam Negeri Kudus, email: rosyidm@yahoo.co.id
}

\begin{abstract}
Abstrak: Komunitas Samin dalam perkawinannya tidak menyertakan peran negara (KUA/Kantor Catatan Sipil) karena ngugemi ajaran leluhurnya (beragama Adam). Tujuan penulisan artikel ini untuk mengetahui faktor yang melatarbelakangi nihilisasi peran negara dalam perkawinan Samin Kudus dan tidak terjadi konflik karena komunitas Samin dijadikan tauladan dalam berinteraksi sosial (dengan warga Samin dan nonsamin), didukung permisifnya interaksi antaranggota masyarakat (warga Kota Kudus) di bidang praktik agama masing-masing. Keberadaan Samin oleh sebagian warga Kudus dianggap punah dan masyarakat Samin pun tidak ingin mengeksplor keberadaan agamanya. Penelitian ini menggunakan metode kualitatif dengan teknik etnografi meliputi wawancara, pencatatan, pengamatan terlibat, dan analisis antarkomponen, dan diperkuat teori grounded dan fenomenologi. Untuk memperkuat data, mengedepankan aspek kredibilitas, transferbalitas, auditabilitas dan dependabilitas (reliabilitas), konfirmabilitas, dan multiangulasi. Teknik perolehan data mengutamakan observasi partisipan sejak tahun 2007 hingga 2009. Adapun tahapan perkawinan model Samin meliputi, nyumuk, ngendek, nyuwito, diseksekno, dan tingkep.
\end{abstract}

Kata kunci: perkawinan, nihilisasi, dan komunitas

Abstract: The Samin Kudus community on them practical marriage is not include of state action (KUA/ CAPIL), because ngugemi set an example for them great-grandfather doctrines (beragama Adam). This article wrote to investigate factors background on the nothingness of state action at Samin Kudus community marriage. The snapshot of their marriage is dis-conflict because they provide good a model on social interaction (Samin dan non-Samin) include permissive interaction between each other at one community (warga Kota Kudus) especially on religious practice. Many people (warga Kudus) assumption that's Samin Community was extinct and they self commitment to closed exploration of their identity. This research utilize qualitative method by ethnography exploration include interview, block note, participation observation, analysis of each component with empowering the grounded theory and phenomenology. To support the data, this research proposes credibility, transferability, audit ability, reliability, confirm ability, and multiangle. This research forward participation observation to collect data between 2007 -2009. The period marriage of Samin model contain; nyumuk, ngendek, nyuwito, diseksekno, and tingkep.

Key words: marriage, nothingness, and community

\section{Pendahuluan}

Pada dasarnya manusia mendambakan terciptanya regenerasi sebagai penerus kekerabatan yang tercipta melalui perkawinan. Agar regenerasi tidak terjadi konflik atau jika terjadi konflik dapat dicari jalan tengah untuk diselesaikan secara damai imbas perkawinan. Jika tidak tergapai, jalur hukum sebagai solusinya, sehingga pelaksanaan perkawinan perlu melibatkan negara (KUA atau Kantor Catatan Sipil) dengan pertimbangan: 1) aspek sahnya perkawinan dibuktikan secara tertulis, masa berlakunya dalam waktu lama karena kategori peristiwa kependudukan (peristiwa penting) yakni kejadian yang dialami seseorang meliputi kelahiran, kematian, lahir mati, perkawinan, perceraian, pengakuan anak, pengesahan anak, pengangkatan anak, perubahan nama dan perubahan status kewarganegaraan (UU Nomor 23 Tahun 2006 Pasal 1 (17)). Adapun pentingnya keterlibatan pemerintah dalam perkawinan karena pengayom, sehingga tercipta hubungan saling menguntungkan dan terwujudnya administrasi kependudukan yang baik dan sistem informasi administrasi 
kependudukan (SIAK) yang rapi; 2) langkah preventif jika terjadi permasalahan, aspek legalformal tertulis tersebut dijadikan pijakan bertanya atau menjawab persoalan, seperti bila terjadi perceraian atau nikah yang diragukan statusnya, seperti jejakakah atau jandakah? Hal itu bertujuan agar tercipta administrasi kependudukan yang rapi. Tetapi realitas sosial mendedahkan bahwa perkawinan masyarakat Samin di Kab.Kudus, Jateng tidak taat secara utuh terhadap UU Nomor 1 Tahun 1974 tentang perkawinan. Meskipun demikian, tidak terjadi konflik horisontal atau vertikal, mengapa? Naskah ini menjawabnya. Jika merunut PP Nomor 55 Tahun 2007, hanya enam agama secara eksplisit disebutkan di negeri ini. Tetapi terdapat komunitas di Kota Kudus yang menamakan diri beragama Adam, dalam prosesi perkawinan pun berpegang pada ajaran agamanya yakni tidak menyertakan peran negara. Pemerintah penyelenggara (fasilitator) perkawinan pun tidak ikut andil menegakkan perundangan. Kecuali pada pertengahan Orba, komunitas Samin pernah dipaksa untuk kawin massal secara islami, sebagian darinya taat pressure pemerintah dan sebagian lainnya masih eksis hingga sekarang dengan agama lokalnya.

Terdapat tiga permasalahan, mengapa perkawinan Samin Kudus yang menihilkan peran negara tidak terjadi konflik? Apa yang dilakukan pemerintah fasilitator pernikahan?, dan bagaimana respon tokoh agama? Tujuan penelitian ini adalah memperoleh jawaban, mengapa masyarakat Samin Kudus yang beragama Adam, dalam melaksanakan perkawinan, tidak melibatkan peran negara, imbasnya pun tidak terjadi konflik, sejauhmana peran pemerintah yang memfasilitasi perkawinan warga negara, dan bagaimana peran tokoh agama yang ada di kota santri, Kudus, memahaminya.

Tujuan penulisan artikel ini dimaksudkan untuk mengetahui faktor yang melatarbelakangi nihilisasi peran negara dalam perkawinan Samin Kudus sehingga tidak terjadi konflik karena komunitas Samin yang dijadikan tauladan dalam berinteraksi sosial (dengan warga Samin dan nonsamin).

\section{Kajian Literatur Teori Grounded}

Teori grounded berawal dari asumsi, data dari empiri, bukan apriori, bangunan teori diperoleh secara alami sesuai kondisi lapangan penelitian, langkah yang dilakukan memahami realita sosialbudaya yang dihadapi, menggali pertanyaan dasar tentang realitas, dan merekonstruksi data dengan hipotesa baru yang dikembangkan menjadi tesa baru (Sudjarwo, 2001:30 dan 61). Menurut Spradley, teori grounded mengembangkan teori berdasarkan data empirik-deskriptif terhadap fenomena kebudayaan (1997:14). Menurut Mudzhar (1998:47) penelitian dengan teori grounded menggunakan metode penelitian sosial-budaya bertujuan menemukan teori melalui data yang diperoleh secara sistematik. Metode yang digunakan analisis komparatif konstan dengan ciri menemukan atau merumuskan teori, datanya sistematik, dan analisisnya komparatif konstan. Dengan harapan munculnya teori pada akhir penelitian, runtutnya alur pikir, kejelasan, kehematan, kepadatan, dan keutuhan dalam operasional penelitian. Muhadjir (1996:86) peneliti berupaya menemukan teori berdasarkan data empiris, bukan membangun teori secara deduktiflogis (disebut grounded theory dan model penelitiannya disebut grounded research), berupaya mencari sosok kualitatif melepaskan pola pikir kuantitatif-matematik, berpedoman pada logika konsisten, masalahnya jelas, efesien, dan integratif. Endraswara memberikan perangkat penelitian dengan teori grounded meliputi: (i) tipe pertanyaan penelitian berupa proses budaya yang terkait dengan perubahan budaya dari waktu ke waktu, (ii) menggunakan paradigma sosiologi dan simbolik interaksionalis (sebagai alternatif), (iii) metode perolehan data dengan wawancara berupa deskripsi proses budaya, (iv) sumber data berupa partisipasi observasi atau catatan harian, (v) informan/partisipannya anggota komunitas budaya, dan (vi) ukuran sampelnya 30-50 informan (2006:99). Penelitian ini 'mengindahkan' teori grounded agar diperoleh hasil penelitian ideal.

\section{Teori Etnografi}

Dalam analisis B. Tedlock (2000:455) etnografi involves an on going attempt to place specific 
encounters, events, and understandings into a fuller, more meaningful context. It is not simply the production of new information or data are transformed into a written or visual form. Menurut Endraswara (2006: 98-99) perangkat teori etnografi meliputi sembilan hal: (i) tipe pertanyaan berupa deskripsi nilai dan kepercayaan kelompok budaya, (ii) menggunakan paradigma budaya, (iii) metode pemerolehan data dengan wawancara tidak terstruktur, observasi-partisipasi, dan catatan lapangan, (iv) dengan sumber data dukung lainnya seperti dokumen, laporan, fotografi, dan diagram hubungan sosial, (v) fokus pertanyaan (bagaimana perasaan dan kesan seorang dalam sebuah budaya), (vi) partisipan/ informan berupa pelaku budaya di masyarakat, (vii) ukuran sampel kurang lebih 30-50 informan/ partisipan, (viii) metode pengumpulan data berupa wawancara in-depth (mendalam) dan observasi partisipan (pengamatan terlibat), dan (ix) hasil yang diharapkan berupa deskripsi fenomena budaya yang sedang, telah, dan (mungkin) akan terjadi.

Teori etnografi menurut Spradley (1997:5) berupaya memerhatikan makna (hasil) tindakan dan fenomena yang dilakukan individu sebagai objek penelitian. Menurut Sudikan (2001:86) penelitian etnografi adalah aktivitas pengumpulan data dilakukan secara sistematik tentang cara hidup dalam berbagai aktivitas sosial-budaya berkaitan dengan berbagai kebudayaan, mengkaji aspek mendasar meliputi apa yang mereka lakukan, apa yang mereka ketahui, dan kendala apa yang mereka gunakan dalam mensikapi kehidupan. Adapun Muhadjir (1996:94) beranggapan penelitian etnografi terkait dunia antropologi yang memelajari peristiwa budaya dan menyajikan pandangan hidup objek studinya. Model ini mendeskripsikan tata cara berpikir, hidup, berperilaku, dengan metode mendeskripsikan kehidupan masyarakat sebagaimana adanya. Dimensi etnografi meliputi induksi-deduktif, generatif-verifikatif, dan konstruktif-enumeratif.

Dimensi induktif diharapkan menemukan teori yang menjelaskan data, sedangkan dimensi deduktif mengharapkan data yang mendukung teori. Dimensi generatif mengarah penemuan konstruktif dan proposisi dengan data eviden, sedangkan dimensi verifikatif adalah mencari evidensi agar hipotesisnya dapat diaplikasikan lebih luas dan universal. Pada dimensi konstruktif, penelitian menemukan konstruksi atau kategori melalui analisis dan proses abstraksi. Sedangkan dimensi enumeratif merumuskan atau menjabarkan unit analisis. Adapun sampel dalam studi etnografi tidak berdasarkan probabilitas dengan prinsip acak (random), tetapi bertahap karena hasil penelitian memiliki komparabel (dapat dibandingkan) dan transbiliabel (dapat diterjemahkan) dengan penelitian lain.

Dalam analisis Muhadjir (1996:98) dasar pijakan penelitian metode etnografi menurut Robert C. Bogdan (1982) terdapat empat hal, yaitu: 1) jadilah praktisi sesuai tingkat kemampuan diri peneliti; 2) pilihlah lokus yang agak asing agar dapat memosisikan diri antara diri sebagai peneliti atau sebagai warga masyarakat,; 3) tidak berpegang secara kaku terhadap rencana dan perlu fleksibel terhadap penelitian terdahulu; dan 4) ambillah topik tertentu yang spesifik. Hal itu diperkuat Muhadjir (1996:126) desain penelitian etnografi dengan model multiple site studies, pengembangan teori bermodal pengalaman berpikir teoretik dan kecakapan menghimpun data untuk mendukung konsep. Etnografi kategori metode naturalistik karena membangun kredibilitas dengan: a) menguji terpercayanya temuan; b) audiensi dengan peneliti lain untuk mengatasi biasnya hasil penelitian; c) analisis kasus negatif berfungsi merevisi hipotesis; d) menguji hasil temuan tentatif dan penafsiran dengan perangkat elektronik atau lainnya; dan e) menguji temuan kelompok perolehan data. Sedangkan menurut Guba, menguji terpercayanya hasil penelitian dengan (i) memperpanjang waktu tinggal di lokasi, dengan tujuan memelajari budayanya, menguji informasi yang salah, dan menumbuhkan kepercayaan; (ii) dalam mengobservasi lebih tekun; dan (iii) menguji dengan cara triangulasi. Triangulasi menurut Denzin menggunakan sumber ganda, metode ganda, peneliti ganda, dan teori yang berbeda-beda (dalam Muhadjir, 1996:126).

\section{Teori Fenomenologi}

Teori fenomenologi menurut Muhadjir (1996:12) berasumsi bahwa objek ilmu tidak terbatas pada sesuatu yang empirik (sensual), tetapi mencakup 
fenomena berupa persepsi (anggapan), pemikiran, kemauan, dan keyakinan subyek tentang sesuatu di luarnya dan mengupas sesuatu yang transenden dan aposteriorik. Metode fenomenologi identik dengan metode rasionalistik yang menolak penggunaan kerangka teori sebagai langkah persiapan penelitian, tetapi mengakui kebenaran etik. Adapun langkah yang dilakukan dalam metode fenomenologi menuntut peneliti (subjek) bergabung dengan objek dengan model pendalaman/penghayatan, dengan ciri logis dan etis. Kelogisan bermakna kebenaran dalam penelitian tersebut hanya mengakui kebenaran secara empirik sensual dan logis, artinya bila dapat dibuktikan secara empirik-inderawi dalam konteks kausal yang dapat dilacak, sedangkan etis adalah kebenaran diakui jika bersifat empiriketik yakni kebenaran yang berdasarkan akal budi untuk melacak, menjelaskan, dan berargumentasi.

Kajian yang mengulas perkawinan dari berbagai aspek diperoleh penulis dari sebelas pustaka antara lain: 1) Syafiin Mansur (2006) dengan topik Poligami dalam Agama Samawi; 2), Kajian tentang pengaturan harta bersama dalam perkawinan poligami (2006) ditelaah Yustiloviani; 3) Telaah tentang ba'ah dalam nikah gratis ditelaah Shafra (2006); 4) Kajian tentang implikasi ijbar nikah terhadap hak reproduksi perempuan (Kajian sosiologis pelaku kawin paksa di Sleman) oleh Miftahul Huda (2006); 5) analisis Samuel Octora (2006) yang 'memotret' dampak negatif mas kawin (belis) pada masyarakat Nusa Tenggara Timur yang masih eksis; 6) Penelitian yang mengidentifikasi karakter personal status poligami dan wali di negara Tunisia, Pakistan, dan Malaysia sebagai sebuah produk hukum Islam oleh Sukhamdi, dkk. (2007); 7) Penelitian memfokuskan keberadaan wali nikah muhakkam (2007) oleh Ajub Ishak; 8) Perkawinan beda agama ditelaah Zakaria (2007) dengan topik Kontroversi Hukum Perkawinan Berbeda Agama; 8) tradisi perempuan meminang di Desa Sambung, Kec. Merakurak, Kab. Tuban, Jatim, Nur Syam (2007); 8) Perkawinan adat ditelaah oleh Trianto dan Titik Triwulan Tutik (2008) dengan titel Perkawinan Adat Wologoro Suku Tengger; 9) Sahnya perkawinan ijab kabul dengan media telepon ditelaah oleh Sadiani (2008). Kesebelas pustaka tersebut, tak satupun mengulas perkawinan Samin, sehingga perkawinan Samin perlu ditelaah.

\section{Metode Penelitian}

Sebelum menentukan metode penelitian, perlu memahami jenis penelitian hasil pemilahan Suprayogo dan Tobroni (2001:8), penelitian berdasarkan bidang keilmuan, metode analisis, dan kualifikasi hasil. Penelitian berdasarkan bidang keilmuan terpilah penelitian sosial, penelitian yang objeknya berupa gejala atau fenomena sosial dan kebudayaan. Sedangkan penelitian berdasarkan metode analisis terpilah kualitatif dan kuantitatif. Analisis kualitatif bertujuan memahami makna yang disimbolkan dalam perilaku masyarakat dan datanya bersifat naturalistik dengan metode induktif dengan model pelaporan deskriptif dan naratif. Analisis Sugiyono (2006:v) penelitian kualitatif biasanya berangkat dari permasalahan yang remang-remang, permasalahan sosial yang kompleks dan mendalam, mengkonstruksikan fenomena sosial yang rumit, menemukan hipotesa dan teori. Metode analisis kuantitatif bertujuan menjelaskan fenomena berdasarkan perspektif peneliti dengan model statistik, biasanya populasinya luas, permasalahannya jelas, teramati dan terukur, dan menguji hipotesis. Adapun berdasarkan kualifikasi hasil, dikategorikan penelitian dasar (basic research) dan penelitian terapan (applied research, operation research, action research). Berdasarkan bidang keilmuan dikategorikan penelitian keilmuan sosial-budaya berobjekkan fenomena sosialbudaya (masyarakat) Samin Kudus berupa model perkawinan adatnya. Metode analisis yang digunakan adalah kualitatif karena memahami perilaku sosial masyarakat Samin Kudus dalam perkawinan. Penelitian ini kategori penelitian terapan bertujuan memahami praktek perkawinan masyarakat Samin Kudus.

Adapun metode penelitian ini terpetakan ciri khas penelitian budaya, penentuan latar penelitian, pemilihan lokus, strategi pengumpulan data, teknik penentuan informan, satuan kajian (unit analisis), teknik analisis data, dan keterandalan data. 


\section{Ciri Khas Penelitian Budaya}

Menurut Featherstone dalam Irwan (1999) terdapat tiga konteks kebudayaan yang perlu diperhatikan peneliti budaya berupa produksi kebudayaan, socio-genesis, dan psicho-genesis. Pertama, produksi kebudayaan dalam dua asumsi, pertimbangan konsumen dan ketertarikan. Jika kebudayaan mendapatkan respon dari konsumen, maka muncul kebudayaan baru, jika kebudayaan mendapatkan daya tarik, muncul inovasi. Kedua, socio-genesis kebudayaan bahwa kebudayaan terikat oleh lingkup (boundary) yang mengitarinya. Lingkup sosial akan menciptakan produk budaya yang lain, karena di antara unsur sosial budaya tersebut saling terkait, bahkan ketergantungan kepentingan. Ketiga, psicho-genesis kebudayaan, kebudayaan tumbuh secara alamiah karena memenuhi kebutuhan batin manusia yang kadangkala jauh dari kepentingan materiil (Endraswara,2006:24). Dalam konteks masyarakat Samin Kudus, faktor psikogenesis dominan karena kebudayaannya tumbuh alamiah didominasi kebutuhan batin. Analisis Endraswara (2006:78) ciri khas penelitian kebudayaan: (i) latar penelitian biasanya spesifik mengungkapkan permasalahan unik dan tertentu, (ii) mengarah pada konteks lapangan (field research), (iii) rancangan penelitian lentur ditentukan kondisi lapangan (data), (iv) data dianalisis sejak penggalian hingga analisis, ( $v$ ) penelitian bersifat sementara, mudah berubah, dan sangat lokatif, (vi) mencari transferbalitas antarfenomena, bukan mencari generalisasi atau rumusan umum, dan (vii) bersifat holistik, integratif, dan interaktif, bukan parsial.

Masyarakat Samin Kudus merupakan komunitas 'khas' yang hidup di pedesaan dan pertanian sebagai urat nadi kehidupannya, memiliki empat perbedaan mendasar dengan nonsamin berupa perkawinannya tidak melibatkan peran negara, penyembelihan hewan (benggang) dan pemulasaraan jenazah dengan 'ritme' tersendiri, dan mengaku beragama Adam (oleh negara dikategorikan aliran kepercayaan). Komunitas ini memenuhi ciri dijadikan penelitian budaya sebagaimana analisis Endraswara dalam tataran spesifik dan konteks lapangan, mengungkapkan permasalahan tertentu yakni model perkawinan Samin, sehingga rancangan penelitian ini lentur karena ditentukan kondisi lapangan (data) dan peneliti akan menggali dan menganalisis data secara tajam dan utuh. Penelitian ini mengalami perubahan dalam hal menggali data, maksudnya semakin banyak data dan tajamnya analisis, peluang diperoleh hasil penelitian yang baik terwujud. Adapun penelitian ini mencari transferbalitas antarfenomena yang bersifat holistik, integratif, dan interaktif dengan berbagai teori yang ada dan penggalian data secara utuh.

\section{Pemilihan Lokus}

Yang dijadikan bahan pertimbangan memilih lokus penelitian pada masyarakat Samin Kudus adalah (i) peneliti telah meneliti komunitas Samin Kudus pada tahun 2006, 2007, dan 2008 dengan menekankan aspek persebaran, geneologi, keberagamaan, dan respon dalam pendidikan formal. Belum diperoleh data oleh penulis, penulis lain yang mengulas aspek perkawinan adatnya, (ii) peneliti hidup dan berdomisili di wilayah Kabupaten Kudus, diharapkan menggali dan menganalisis data diperoleh kemudahan mengakses, dan (iii) peneliti belum menemukan kajian khusus sebagaimana poin (i).

\section{Strategi Pengumpulan Data}

Pengumpulan data menggunakan strategi etnografi, menurut Sudikan (2001:105) dengan wawancara, pencatatan, dokumentasi, pengamatan terlibat, dan analisis antarkomponen. Pertama, Wawancara; menggali data dengan dialog yang ditujukan pada objek penelitian dengan menyediakan catatan yang diperlukan sebagai data. Menurut Endraswara (2006:164) wawancara dapat dilaksanakan secara informal, terstruktur atau tidak terstruktur, dapat juga semi terstruktur, oleh tim atau mandiri, tertutup atau terbuka, dapat juga dengan menggali riwayat secara lisan. Dalam penelitian ini menggunakan wawancara informal, tidak terstruktur, terbuka, dan proses penggalian secara lisan dengan pertimbangan lebih praktis. Kedua, pencatatan hal-hal yang terjawab oleh objek penelitian berdasarkan pertanyaan peneliti dan dikembangkan sesuai dinamika data. Ketiga, dokumentasi; merupakan data yang bersumber dari karya tertulis sebagai pijakan telaah dapat 
berupa jumlah komunitas, jenjang pendidikan, analisis faktor, dan produk hukum. Dalam penelitian ini difokuskan analisis faktor melaksanakan perkawinan yang tanpa melibatkan peran negara. Keempat, pengamatan terlibat; secara langsung terhadap aktivitas yang dilakukan terhadap objek penelitian dalam aktivitas kehidupan sehari-hari dari berbagai sisi kehidupannya terutama kaitannya dengan topik penelitian. Peneliti singgah secara periodik bersama dengan komunitas Samin Kudus dengan harapan diperoleh data yang murni. Kelima, analisis antarkomponen; dengan tujuan mengombinasikan dan memformulasikan seluruh teknik pengumpulan data yang dilakukan secara padu. Kelima strategi pengumpulan data tersebut digunakan agar diperoleh hasil analisis ideal.

\section{Teknik Penentuan Informan dan Satuan Kajian}

Informan penelitian adalah delapan masyarakat Samin Kudus (perwakilan), dua tokoh Samin, dua tokoh masyarakat non-Samin, unsur pemerintah Kab. Kudus penyelenggara perkawinan (KUA) (Kepala KUA dan Naib), dan empat masyarakat nonsamin (tetangga) Samin dengan tujuan diperoleh data yang utuh dan ideal. Sedangkan yang dijadikan unit analisis (i) ketua kelompok (botoh) masyarakat Samin, (ii) masyarakat Samin secara random, (iii) unsur pemerintah Kab.Kudus penyelenggara perkawinan, (iv) masyarakat nonsamin, khususnya yang intensitas komunikasinya dengan masyarakat Samin dekat-rapat, dan (vi) unsur lain sebagai penunjang-pemerkuat perolehan dan validitas data. Dilakukannya hal tersebut bertujuan diperoleh data utuh dan valid.

\section{Teknik Analisis Data}

Teknik ini menggunakan kajian etnografi, analisis riwayat hidup, dan analisis isi. Kajian etnografi bertujuan memahami aktivitas budaya masyarakat Samin, Kudus dalam praktik perkawinan. Diharapkan menemukan aspek yang melatarbelakangi tidak diikutsertakannya negara dalam perkawinan Samin dan dampak lain yang ditimbulkannya seperti anak yang dilahirkan kaitannya dengan administrasi kependudukan dan lainnya. Sedangkan analisis riwayat hidup; bertujuan memahami faktor yang melatar- belakangi model perkawinannya. Untuk mendapatkan data yang andal, menurut Maryaeni (2005:27) dan Endraswara (2006:110) menggunakan model triangulasi sumber data, pengumpulan data, metode, dan teori. Triangulasi sumber data; langkah ini mencari data dari sumber sebanyak-banyaknya (terukur sesuai kebutuhan penelitian) atau dari berbagai sumber yang terlibat secara langsung kaitan dengan penelitian. Triangulasi pengumpulan data; mencari data dari berbagai sumber yang tidak berkaitan langsung dengan penelitian, dengan harapan diperoleh data dukung yang bersifat memperkuat data utama. Triangulasi metode; memperoleh variasi dan keakuratan hasil penelitian karena proses perpaduan antara observasi (pengamatan terlibat), wawancara, dokumentasi, dan lainnya. Sedangkan triangulasi teori mengecek sumber data tentang kevalidan dan keakuratan dari berbagai metode berupa data mentah dalam bentuk : a) catatan lapangan, dokumentasi, dsb; b) hasil analisis bersumber dari konsep; c) hasil sintesis data (tafsiran, simpulan, definisi, laporan akhir), dan d) catatan proses yang digunakan (metode, strategi, dan prosedur).

Untuk memperkuat data, menurut Endraswara (2006:111) mengedepankan aspek kredibilitas, transferbalitas, auditabilitas dan dependabilitas (reliabilitas), konfirmabilitas, dan triangulasi. Kredibilitas merupakan cara mendapatkan data dengan model: (i) memperpanjang alokasi waktu (sesuai tarjet waktu yang direncanakan secara maksimal) mengobservasi dengan mempertimbangkan aspek sangkilmangkus agar mengenal responden lebih dekatakrab dalam batas kewajaran, diharapkan mampu membuka katup pandora yang menutupi (esensi) budayanya menjadi data penelitian yang valid dan aktual, (ii) peer debriefing, membicarakan materi dan permasalahan penelitian kepada pihak lain yang memiliki concent dengan materi penelitian yang digarap oleh peneliti, dan (iii) member check, pengulangan setiap persoalan jika terdapat kesalahan dengan pertimbangan terhindar kesalahan data dan lainnya. Transferbalitas dilakukan dengan validitas eksternal, apakah penelitian ini dapat diterapkan atau disejajarkan dengan kasus (fenomena penelitian lain yang bermaterikan identik) untuk dicari kesamaan dan 
perbedaan. Dalam hal ini peneliti tidak menemukannya sehingga tidak muncul kesamaan atau perbedaan hasil penelitian. Auditabilitas dan dependabilitas (reliabilitas); bertujuan memperoleh kesamaan hasil penelitian jika diadakan pengulangan (penelitian) agar diperoleh konsistensi dengan teknik pengamatan oleh dua orang atau lebih terhadap realitas budaya, checking data dengan mencari data dari orang lain, dan audit trail yakni dilakukan pembimbingan untuk memeriksa selama proses konsultasi. Sedangkan konfirmabilitas merupakan cara memperoleh kebenaran data dan hasil analisis data dengan mengonfirmasi (cek silang dan cek ulang) terhadap komunitas lain di sekeliling objek yang diteliti. Hal ini dilakukan peneliti dengan cara memberi kesempatan pada tokoh dan warga Samin untuk membaca ulang hasil penelitian ini. Triangulasi merupakan penggabungan tiga hal yakni sumber data, pengumpulan data, dan teori. Diharapkan hasil penelitian dipahami dengan benar dan jelas alur perolehan data dan proses analisisnya. Tetapi, karena peneliti tidak menemukan komponen transferbalitas, yang dilakukan dwiangulasi.

Strategi pengumpulan data mengedepankan wawancara dan didukung dengan pencatatan, dokumentasi, pengamatan terlibat, dan analisis antarfaktor. Teknik penentuan informan dengan delapan masyarakat Samin (perwakilan karena proaktif jika digali sebagai sumber data dan ekstrofet), dua tokoh Samin yang melek huruf dan ekstrofet, pihak pemerintah (Kepala KUA Kec. Undaan, Kudus dan seorang Naib KUA) dan empat tetangga Samin (nonsamin). Adapun teknik analisis datanya dengan kajian etnografi.

\section{Hasil Penelitian dan Pembahasan}

Prinsip pernikahan Samin, anak (calon mempelai) laki-laki atau perempuan mempunyai orang tua, orang tua perempuan (ibu) berkewajiban merukunkan anak dan orang tua lelaki (bapak) berkewajiban menyetujui anak dalam melaksanakan pernikahan, sehingga yang berkewajiban dan berhak menikahkan anak adalah orang tuanya. Jika orangtuanya tiada maka kakak dari orangtua atau adik dari orangtua yang mewakilinya. Meskipun sebelum tahun 1950-an, masyarakat Samin Kudus jika mengadakan perkawinan dalam tahapan paseksen/nyeksekno, kedua mempelai beserta keluarganya mendatangi kediaman petinggi (kepala desa) karena desa (saat itu) belum memiliki balai desa. Kedatangan masyarakat Samin di kediaman kepala desa sebagai pengakuan keberadaan pemerintahan desa, sehingga diharapkan ikut menyaksikan perkawinan. Mengapa setelah tahun 1950-an tidak mendatangi kediaman kepala desa? Masyarakat Samin beranggapan kepala desa (saat ini) tidak memiliki kekuasaan penuh (ora duwe bok) dari rakyat, kekuasaan sepenuhnya di tangan rakyat sendiri.

\section{Tahapan Perkawinan Samin}

Pernikahan masyarakat Samin Kudus mayoritas antarsesama pengikut Samin (tunggal bibit) dilatarbelakangi intensitas berinteraksi dengan prinsip angan-angan dalam benak (partikel), dipertimbangkan secara mendalam (artikel), dilampiaskan dalam komunikasi verbal (pengucap), dan ditindaklanjuti perkawinan (laku/kelakuan). Dalam pernikahan antarpengikut Samin memiliki janji yakni janji sepisan kanggo selawase, meskipun dalam praktiknya terjadi perceraian. Adapun tahapan perkawinan model Samin meliputi, nyumuk, ngendek, nyuwito, diseksekno, dan tingkep.

\section{Nyumuk}

Nyumuk adalah kedatangan keluarga (calon) kemanten putra ke keluarga (calon) kemanten putri untuk menanyakan keberadaan calon istri, apakah sudah mempunyai calon suami atau masih gadis (legan). Jika belum memiliki calon suami, selanjutnya, pihak keluarga calon kemanten putra menentukan hari untuk ngendek. Proses nyumuk biasanya kedatangannya tidak menyertakan banyak saudara atau teman, tidak sebagaimana acara ngendek.

\section{Ngendek}

Ngendek adalah pernyataan calon besan dari keluarga kemanten putra kepada bapak-ibu (calon) kemanten putri, menindaklanjuti forum nyumuk. Pelaksanaan ngendek diawali pernyataan calon kemanten putra kepada bapak-ibunya bahwa dirinya berkeinginan mempersunting seorang putrinya. Dalam prosesi ngendek, ibu kemanten putra memberi cincin emas kepada calon kemanten putri (calon menantu) sebagai 
tanda telah diendek (diwatesi). Ngendek dihadiri tokoh Samin, keluarga Samin, dan tetangganya yang berajaran Samin dan non-Samin. Dalam prosesi ngendek, besan (keluarga dari calon kemanten putra) kedatangannya membawa 'buah tangan' yang biasanya berupa hasil bumi dan jenis makanan yang biasanya dihidangkan bagi tamu.

Setelah tamu dan rombongan dari calon besan (bapak kemanten putra) menempati tempat yang disediakan tuan rumah (bapak-ibu kemanten putri), hidangan berupa makanan ringan (snack) dan minuman disediakan bagi tamu untuk dinikmati (dirahapi) bersama. Acara dimulai pernyataan pembuka dari besan (bapak-ibu kemanten laki-laki), dalam prosesi ini bapak Wargono: kang, anggonku mrene sak rombongan duwe karep, siji, pingin merohi kahanane sedulurku ing kene, opo yo podo sehat kewarasan, semono ugo aku sak rombongan kahanane wilujeng-sehat, nomer loro, aku duwe karep, minongko enggenepi karepe anak ku lanang kang aran Karsidi, nekok ake, opo turunmu wong jeneng wedok pengaran Iin Kustianingsih, wes duwe calon, yen durung, bakal dikarepake turunku. Pernyataan tersebut dijawab oleh calon besan (bapak kemanten putri): turunku Iin Kustianingsih, legan. Pernyataan dilanjutkan oleh tokoh Samin (Bpk. Wargono dan Bpk.Sumar keduanya berdomisili di Kaliyoso) bahwa prosesi ngendek sudah disaksikan oleh forum, sekaligus memberikan pesan (sesorah) agar kedua calon besan sabar menunggu menuju proses perkawinan/nyuwito selanjutnya proses paseksen. Setelah prosesi ngendek berakhir, tuan rumah mempersilahkan tamu menikmati hidangan yang disediakan.

Dalam prosesi ngendek tersebut, calon kemanten putra tidak ikut menghadiri acara, karena diwakilkan kedua orang tuanya. Adapun penempatan waktu di malam hari dengan pertimbangan, miturut sipatane wong sikep, mergo yen bengi iku kanggo tatane uwong, yen rino kanggo tatane sandang pangan (waktu malam dipergunakan untuk istirahat atau bercengkerama dengan keluarga, sedangkan di siang hari saat mengais rizki).

\section{Nyuwito-Ngawulo}

Nyuwito adalah hari dilangsungkan perkawinan didasari niat kemanten putra untuk meneruskan keturunan (wiji sejati, titine anak Adam). Setelah pasuwitan, biasanya kemanten putra hidup bersama keluarga kemanten putri dalam satu rumah (ngawulo) atau kemanten putri hidup bersama keluarga kemanten putra, berdasarkan kesepakatan antarbesan. Selama proses ngawulo, kemanten membantu melaksanakan pekerjaan yang dilaksanakan mertuanya. Pelaksanaan nyuwito dengan runtutan acara: pertama, pemandu acara (Bpk. Sudarmo) membuka acara: Bapak-bapak, ibu-ibu, soho sederek sedoyo, menawi kulo bade rembakan, nyuwun sewu kulo bade ngaturake salam kulo, gadah printah saking sedulur Maskat, jenengan diaturi kendel saantawis mbok bilih wonten salah anggen kulo kondo nyuwun pangapunten; kedua, pernyataan besan kemanten putra menindaklanjuti pembuka dari pembawa acara: Amit poro pinisepuh, pak Maskat (nama besan) aku tekan kene perluku rembukan karo kowe, aku ngendek turunmu, wes tak wujudake, ben bocahe jawab dewe..., ; ketiga, pernyataan kemanten putra (Nurkan) di hadapan mertua dalam forum pasuwitan: Pak kulo dateng mriki pingin sumerep seger kuwarasane Pak Maskat, kulo ajeng takon kaleh panjenengan, jenengan gadah turun wong jeneng wedok pengaran Ana Kustianawti (calon istri) nopo taseh legan?; keempat, jawaban mertua (bapak kemanten putri, Maskat): yo le, ijeh legan; kelima, pertanyaan kemanten putra berikutnya: niku ajeng kulo rukun tatanane wong sikep rabi, enjeng nek pun podo seneng, jenengan pripon pak? nopo lego? keenam, jawaban mertua (Maskat): yo le... opo kuwe sabar, opo nrimo?, ketujuh, jawaban kemanten putra (Nurkan): ajeng kulo tunggu minongko nyuwito, nyiwita-ake partikel, artikel, pengucap lan kelakuan seng kados ndiko lakoni, kedelapan, respon mertua (Maskat): yo nek karepmu koyok ngono le, rembukmu titenono dewe, rembukku tak titenane dewe kanggo selawase; kesembilan, pernyataan mertua (ibu kemanten putri, Kustin):le aku wong jeneng wedok, sak dermo ngrukunake, tak jak nyandang pangan sak wujude, kuwe yo opo sabar?opo yo nrimo?; kesepuluh, jawaban kemanten putra: nrimo mbok?, kesebelas, pernyataan ibu Kustin: yo gunemu dewe titenono, gunemku tak titenane dewe, kedua belas, prosesi brokohan, pernyataan sesepuh (Bapak Sumar): (menyebut nama tuan rumah) Maskat gadah tembung kaleh kulo gadah niat brokohan, brokohi turun kulo, ditunggu kaliyan 
(menyebut nama kemanten putra), Nurkan, mugi kangge sak lami-laminipun, niku ndiko tindakke, ketiga belas, pernyataan dari besan (bapak kemanten putra, Sumiran): (menyebut nama besan) Pak Maskat, iki dino bocah wes ndok kene, dadi wajibmu yo tuturono, keempat belas, dijawab besan (mertua kemanten putra, Maskat): yo kang, yo wes tak titeni rembukku, yo wajibku ngandani, kelima belas, kemanten putri beserta ibunya meninggalkan forum pasuwitan (pasemon) untuk mempersiapkan hidangan kepada tamu undangan.

Dalam acara brokohan, menghidangkan sajian dua ingkung ayam, segumpal nasi yang ditaruh pada dua nampan yang beralaskan daun pisang, bubur putih dalam satu piring dan bubur merah dalam satu piring, minuman teh dalam gelas, dan krupuk goreng yang dikemas plastik disajikan tuan rumah kepada tamu di barisan prosesi pasuwitan. Variasi hidangan brokohan sesuai selera masingmasing tuan rumah. Acara rehat makan malam bersama antara tuan rumah dengan tamu menyajikan hidangan berupa beberapa nasi dalam bakul yang jumlahnya berdasarkan jumlah tamu, misalnya: satu bakul nasi diperuntukkan bagi sepuluh orang dan hidangan/kudapan sebagaimana sebelum prosesi nyuwuk (tertuang dalam paragraf di bawah). Keenam belas, pernyataan besan (bapak kemanten putra) minta pamit untuk undur diri dari forum menuju kediamannya, dan ketujuh belas, pernyataan besan (bapak kemanten putri) mempersilahkan besan dan tamu lainnya kembali ke kediaman masing-masing.

Meskipun sebelum prosesi nyumuk (sebelum kedatangan besan putra) tuan rumah dari kemanten putri (tempat singgah peneliti), menghidangkan berupa air minum dalam kendi, makanan tradisional berupa ketan salak yang dibungkus daun, pisang goreng tanpa bungkus, bugis yang dibungkus daun, cucur dibungkus plastik, dan gandos yang dibungkus plastik dihidangkan dalam sebuah piring yang terbuat dari alumunium, dan rokok berupa Sukun kretek, sukun filter, dan senior (Rokok tersebut merupakan rokok yang menjadi konsumsi harian masyarakatnya).

\section{Paseksen}

Forum paseksen merupakan forum ungkapan kemanten putra di hadapan orang tua (mertua) yang dihadiri kemanten putri, keluarga, dan tamu undangan warga Samin dan Nonsamin. Ungkapan tersebut setelah kemanten putra-putri melangsungkan hubungan suami-istri (kumpul) dengan runutan acara berikut ini. Pertama, pernyataan tuan rumah (besan/bapak kemanten putri, Suwito) dumateng sedulur kulo sedoyo, poro mbah, poro bapak, ibu, kadang kulo seng pernah nem, jaler miwah estri sing wonten mondoane kulo mriki. Kulo niki gadah kondo mangke do ndiko sekseni. Kulo duwe turun wong jeneng wedok pengaran Nita Rahayu, empun dijawab wong jeneng lanang pengaran Agus Gunawan, kulo mpon ngelegaake, yen miturut kandane wong jeneng lanang pengaran Agus Gunawan turune tatanane wong sikep rabi pun dilakoni (selanjutnya dijawab forum: nggih). Niku kondo kulo do ndiko sekseni piyambak (dijawab forum: nggih). Kedua, pernyataan kemanten putra (syahadat): kulo duwe kondo ndiko sekseni. Kulo ajeng ngandaake syahadat kulo, kulo wong jeneng lanang pengaran Agus Gunawan, toto-toto noto wong jeneng wedok pengaran Anita Rahayu, kulo sampun kukuh jawab demen janji, janji sepisan kanggo selawase, inggih niku kondo kulo ndiko sekseni (dijawab forum: yo le..). Ketiga, doa oleh tokoh Samin (nyintreni) untuk keselamatan bagi kedua mempelai. Setelah itu keempat, acara brokohan, tamu mendapatkan hidangan dari tuan rumah.

Satu catatan, perkawinan antara Agus Gunawan dengan Anita Rahayu berdasarkan pilihan anak, tidak melalui prosesi perkawinan Samin secara utuh yakni tanpa nyumuk dan ngendek oleh orangtua kandungnya. Adapun prosesi nyuwito oleh dirinya sendiri, tidak oleh orang tua Agus (Bpk.Wargono). Berdasarkan pengakuan ibu Masinah (ibunya Anita Rahayu) bahwa saat ngendek muncul kesepakatan karena anak (Anita) masih balita, bagaimana jika terjadi perubahan nantinya, keluarga Nuryanto memahaminya. Meskipun Agus Gunawan oleh orang tuanya (Wargono) telah ngendek dengan seorang putri, Widodo, asal Desa Bombong, Kec. Sukolilo, Kab.Pati. Sehingga pernyataan dalam forum nyuwito, tidak sebagaimana nyuwito ketika 
prosesi perkawinan yang mendapatkan ijin dari orangtua.

Begitu pula, problem yang dialami Gumani (putra Bpk. Sumar) yang telah nyumuk dengan Fitriya Kiki Fatmala (Putri Bpk.Maniyo) dari Kab.Pati. Karena Fitri pasca disumuk Gumani tidak cocok untuk melanjutkan tahapan perkawinan berikutnya, ngendek dan seterusnya. Sebagaimana pernyataan Bpk. Maniyo kepada Bpk. Sumar "kulo pengen sumerep kahanane jenengan, nopo sami seger kewarasan. Semonten ugi kulo seger kewarasan. Kapindone, putri kulo mboten purun jejodohan kalayan Gumani, tinimbang dipun pekso. Pangapuntene". Dijawab Bpk. Sumar "Pancen durung jodone yo...Maniyo. Senajan ora sido dadi besan, seduluran tetep mbok lanturno". Dijawab Bpk. Maniyo "Inggih, kulo mboten bade supe, mboten bade kulo pedot". Adapun pernyataan Gumani, kranten roso mboten saget dipekso, kersane ...Mungkin kulomangkeh wonten ingkang luweh sae kagem kulo lan kagem dek Pipit (Fitriya). Jadi dengan tidak dilanjutkannya tahapan dan prosesi perkawinan tersebut, tidak menyisakan.

\section{Tingkep}

Setelah penganten hamil dalam usia kandungan tujuh bulan, diadakan prosesi selamatan bayi dalam kandungan yang disebut brokohan. Dalam acara brokohan, sesepuh Samin (botoh) yang mewakili si empunya hajat memberikan petuah (nyondro) kepada hadirin dengan ungkapan: poro sederek, kondo kulo ndiko sekseni. Kulo gadah niyat tiyang sekalian, karep brokohan, kawitan hinggo wekasan, brokohi sageto sae, ngajeng ngantos wingkeng dateng turun kulo asale ngandut turune sampon pitung sasi. Anake kulo brokohi sageto sae ngantos ngajeng lan wingking. Tiyang sekalian gadah niat brokohi kersane bantu sageto waras ngajeng ngantos wingkeng. Danyange kulo brokohi kersane sae, ngajenge ngantos wingkinge kulo brokohi rinten kalayan ndalu kersane bantu karepe tiyang sekaliyan.

\section{Pernik Perkawinan}

Pernik perkawinan meliputi undangan, lokasi pasuwitan, tamu yang hadir, hidangan yang disajikan, pakaian kemanten, dan pakaian tuan rumah

\section{Undangan dan Lokasi Pasuwitan}

Undangan dari tuan rumah kepada tamu yang berasal dari tetangga dekat yang berasal dari komunitas Samin dan non-Samin dan saudara yang berdekatan rumah atau jauh dari rumah (ukuran jauh adalah di luar wilayah administrasi desa tuan rumah) yang mengundang adalah yang berhajat dengan pernyataan: amit bpk/ibu/sederek (menyebutkan nama yang diundang) asal kulo mriki bade weroh seger kuwarasane keluarga, kulo gadah butuh mbenjang dinten Rebo wanci ndalu, kulo bade ketekan mantu, panjenengan kulo aturi nderek nyekseni.

Penataan lokasi pasuwitan terpilah bangsal ijab dan kursi tamu undangan. Bangsal ijab yang terdiri dari beberapa kursi berhadapan antara rombongan kemanten putra dengan keluarga kemanten putri dan dipisahkan oleh meja yang digunakan untuk sajian hidangan (makananminuman). Karena jumlah tamu undangan melebihi jumlah kursi yang tersedia, maka bagi tamu kaula muda menempati tempat duduk dengan lembaran tikar.

\section{Media Sosialisasi dan Tamu yang Hadir}

Masyarakat Samin Kudus dalam mensosialisasikan (mengundang) calon tamu yang diundang dalam perkawinan menggunakan pola hadir secara langsung ke rumah calon yang diundang. Dalam pemahaman penulis, masyarakat Kudus nonSamin menggunakan media sosialisasi dengan undangan tertulis, meskipun ada kalanya undangan tertulis bersamaan dengan menghadiri secara fisik kepada calon tamu yang diundang. Tidak menggunakan undangan secara tertulis, bagi masyarakat Samin Kudus karena masyarakat Samin tidak terbiasa memanfaatkan model undangan tertulis dan sosialisasi dengan hadir secara fisik merupakan model yang dilakukan oleh leluhurnya.

Tamu yang hadir dalam prosesi perkawinan Samin Kudus meliputi tokoh Samin, saudara masyarakat Samin yang berajaran Samin, saudara masyarakat Samin yang berajaran non-Samin (Islam), tetangga masyarakat Samin yang berajarkan Samin, dan tetangga masyarakat Samin yang berajaran non-Samin. Bagi warga Samin karena kedekatan tempat tinggal, orangtuanya hadir disertai anak-anaknya untuk 
menyaksikan prosesi perkawinan dan anak yang beranjak dewasa membantu tuan rumah menghidangkan makanan untuk tamu yang hadir.

\section{Hidangan yang disajikan}

Hidangan yang disajikan tuan rumah berupa makanan ringan (snack), makanan besar (nasi dan lauk-pauk), minuman teh gelas dan air kendi. Sedangkan hidangan pasca-makan adalah pisang dan rokok yang difavoritkan adalah sukun kretek, sukun filter, dan senior (produk pabrik rokok Kudus). Makanan ringan tersebut berupa makanan tradisional buatan tuan rumah dan makanan non-tradisional. Makanan tradisional berupa ketan salak, bugis, cucur yang dibungkus dengan daun pisang, dan pisang goreng. Adapun makanan non-tradisional berupa emping goreng, kue, roti, buah-buahan, dsb. Sedangkan makanan besar berupa gulai pindang daging sapi/kerbau.

Tetapi ketika prosesi brokohan sajian yang dihidangkan berupa nasi yang ditaruh di atas baki yang beralaskan daun pisang, seekor ingkung ayam, bubur putih dan bubur merah dalam piring, krupuk goreng, dsb. Sajian ini sesuai dengan kemampuan dan dalam takaran sewajarnya, tidak karena ajaran.

\section{Pakaian Kemanten, Tuan Rumah, Besan, dan Tamu}

Pakaian kemanten Samin laki-laki adalah baju dan celana tokong/komprang, lazimnya berwarna hitam atau bersarung (bebet), berblangkon atau iket/udeng kepala, sedangkan bagi kemanten putri mengenakan pakaian Jawa/beskap. Pakaian tuan rumah mengenakan baju khas Samin, ada juga yang mengenakan pakaian lazimnya masyarakat Jawa (baca: Indonesia) ketika di rumah. Begitu pula pakaian tamu dari besan, tak bedanya pakaian tamu dari non-besan, hal itu merupakan selera pemakainya.

\section{Perkawinan Samin yang Berbeda dengan Masyarakat NonSamin}

Prosesi pernikahan masyarakat Samin pada umumnya tanpa menyertakan pengeras suara, tanpa musik pengiring acara, tanpa dekorasi pelaminan penganten, tanpa pelaminan khusus (kemanten hanya duduk di kursi berbaris satu lajur untuk besan dan satu lajur untuk tuan rumah, tokoh Samin, dan saudara dekatnya), tanpa tenda, tanpa undangan tertulis, hanya tersedia bangku, kursi, dan tikar untuk tamu. Bagi yang mampu perekonomiannya, dimeriahkan pertunjukan seni Jawa, seperti kethoprak, wayang kulit, tayub, dsb. Tetapi bagi masyarakat Kudus yang non-Samin jika mengadakan acara perkawinan pada umumnya menyewa pengeras suara beserta amplifiernya, berdekorasi, adanya pelaminan kemanten, bertenda, membagikan undangan tertulis, tersedia kursi tamu dalam jumlah besar, dsb.

Masyarakat Samin Kudus dalam melaksanakan perkawinan tanpa prosesi nonjok juga tanpa sentuhan budaya masyarakat Kudus seperti arak-arakan kemanten dalam proses perkawinan pascaijab kabul yakni pertemuan calon mempelai yang disaksikan publik secara terbuka dengan sentuhan budaya lokal yang kental (meskipun tradisi ini secara perlahan telah bergeser/berkurang). Hanya saja proses perkawinan Samin dan non-Samin sama-sama mengundang saudara dan tetangga yang mengikuti ajaran Samin dan non-Samin, menyelenggarakan slametan perkawinan yang dilaksanakan (biasanya) sebelum acara ijab qobul antara calon mempelai laki-laki dengan calon mempelai perempuan berupa walimatul urusy (slametan yang disunahkan dalam pernikahan versi Islam) dan dilanjutkan slametan 'rasulan' dengan menu khas berupa ingkung (seekor ayam jantan yang dimasak khas).

\section{Prinsip Perkawinan Samin Kudus}

Prinsip pernikahan Samin, pertama, bahwa anak (calon mempelai) antara laki-laki dan perempuan mempunyai orang tua, orang tua (ibu) berkewajiban merukunkan anak dan orang tua (bapak) berkewajiban menyetujui anak melaksanakan pernikahan, sehingga yang berkewajiban dan berhak menikahkan anak adalah orang tuanya sendiri. Mengapa tidak melalui administrasi pemerintahan (KUA atau catatan sipil)? Karena pemerintahan adalah lembaga yang dijalankan oleh manusia, bapakibu Samin juga manusia, sehingga pernikahan itu telah terwakili oleh bapak-ibu yang juga "manusia". Jika bapak/ibu kandung kemanten meninggal dunia (tiada) maka yang menyerahkan 
kemanten adalah Pak de (kakak dari orang tua kandung kemanten), dan jika Pak de tidak ada, diwakilkan pada Pak lek (adik kandung bapak kemanten putra). Kedua, bahwa adanya anak Adam (manusia) karena melalui proses sikep-rabi (persetubuhan) antara Adam dengan Hawa yang tanpa melibatkan pihak lain sebagai saksi atau pencatat (buku) nikah, hal tersebut diikuti pengikut Samin (Putu Adam) hingga kini. Keberadaan Adam menduduki alam (jagat whongwhong) masa lalu seorang diri, maka Yai (Tuhan) menurunkan Adam (Yai Adam) ke dunia agar tidak sendirian dan tercipta kehidupan (ora suwung), Adam sikep-rabi (kawin) dengan Hawa (Ibu Hawa) yang disaksikan oleh Yai (Tuhan).

\section{Perceraian, Warisan, dan Pantangan}

Dalam penggalian data, peneliti menemukan perceraian masyarakat Samin Kudus sebagaimana dialami (i) Ibu Masini (warga Samin dari Kaliyoso) dengan suaminya Bpk.Suwarjo (warga Samin dari Bombong, Pati), (ii) Bpk. Kiran (asal Bombong) dengan Ibu Sutimah (asal Kaliyoso), perkawinannya hanya sampai periode nyuwito, (iii) Bpk. Kusnan dengan Ibu Kastinah (keduanya dari Kaliyoso), perceraian diduga karena adanya 'WIL', dan (iv) Bpk. Sulasno (asal Kaliyoso) dengan Ibu Wiji (asal Bombong, Pati) akibat keinginan Lasno untuk berumah tangga di Dukuh Kaliyoso, Kudus, sedangkan Wiji menghendaki membangun rumah di Desa Bombong, Pati. Keinginan keduanya tidak dapat disatukan, masing-masing bersikukuh dengan keinginannya. Setelah terjadi perceraian, Lasno menikah dengan Winarsih, warga Kaliyoso secara Islam.

Adapun jika terjadi perceraian maka yang dilakukan suami menyerahkan istri kepada mertuanya karena ketika perkawinan mendapat persetujuan mertua, sehingga ketika perceraian pun diserahkan kepada mertua. Untuk pembagian harta gono-gini (harta milik suami-isteri yang diperoleh setelah perkawinan) dilakukan dengan musyawarah untuk menentukan pembagian perolehan istri, suami, dan anak berdasarkan kesepakatan keluarga. Proses pembagian harta warisan jika terjadi perceraian atau lainnya, harta hasil gono-gini atau non-gono-gini dibagi rata atau diberikan pada keturunannya dalam jumlah tertentu setelah disepakati antara mantan suami- istri. Pada dasarnya, pembagian tersebut berdasarkan kesepakatan mufakat agar tidak terjadi konflik.

Pantangan perkawinan masyarakat Samin Kudus berupa perkawinan dengan saudara kandung, pernikahan sejenis (homoseks), dan beristri lebih dari satu, hal tersebut dianggap faktor terjadi konflik dalam keluarga, sehingga diantisipasi, dan ketiga hal tersebut nenekmoyang Samin tidak melakukannya.

\section{Perkawinan Samin Perspektif Hukum Positif}

Jika berpijak pada UU Nomor 1 Tahun 1974 tentang perkawinan, terdapat hal 'krusial' yang perlu diklarifikasi; pertama, Pasal 2 (1) tiap perkawinan dicatat menurut peraturan perundangan yang berlaku. Samin Kudus tidak mengenal pencatatan pernikahan karena tidak diwariskan leluhurnya; kedua, Pasal 7 (1) perkawinan hanya diijinkan jika pihak pria mencapai umur 19 tahun dan pihak wanita mencapai 16 tahun. Sebagian masyarakat Samin sangkak beranggapan usia calon mempelai tidak memiliki batas minimal. Hal ini berdasarkan argumen, manusia lahir dalam kondisi tak memiliki usia dan standar dilangsungkannya pernikahan ketika mereka siap menikah. Adapun strata usia masyarakat Samin terpilah adam timur, adam brahi, dan wong sikep kukuh wali adam. Adam timur adalah generasi Samin yang belum dewasa, belum memiliki 'rasa' dengan lain jenis. Sedangkan adam brahi adalah generasi Samin yang telah dewasa dan memiliki 'rasa' terhadap lawan jenis. Adapun wong sikep kukuh wali Adam adalah orang Samin yang telah berkeluarga. Ketiga, Pasal 26 (1) perkawinan dilangsungkan di muka pegawai pencatat perkawinan yang tidak berwenang, dapat dibatalkan. Samin Kudus memegang prinsip tanpa menghadirkan petugas KUA atau Kantor Catatan Sipil karena mengikuti tradisi moyangnya. Keempat, Pasal 28 (1) batalnya perkawinan setelah keputusan pengadilan berkekuatan hukum tetap. Batalnya perkawinan versi masyarakat Samin jika kedua mempelai berpisah secara alamiah karena berbagai hal, sehingga (mantan) suami menyerahkan (mantan) istrinya kepada (mantan) mertuanya. Kelima, Pasal 29 (1) pada waktu atau sebelum perkawinan dilangsungkan, kedua pihak atas persetujuan bersama dapat mengadakan perjanjian tertulis 
yang disahkan pegawai pencatat perkawinan. Masyarakat Samin pun tidak disentuh oleh budaya tulis-menulis dalam proses pernikahan karena budaya leluhurnya tidak mengajarkan pencatatan perkawinan. Pasal 42: anak yang sah adalah anak yang dilahirkan akibat perkawinan yang sah. Dalam konteks hukum positif nasib anak Samin pun 'terlempar' dari ranah hukum positif. Berdasarkan Peraturan Menteri Agama (Permenag) Nomor 3 Tahun 1975 Pasal 22: akad nikah dilangsungkan di hadapan pegawai pencatat nikah. Dalam realitasnya, perkawinan yang dilakukan oleh masyarakat Samin Kudus hanya menyertakan masyarakat Samin dan nonSamin, tanpa melibatkan peran negara (mulai dari kepala desa hingga unsur penyelenggara pernikahan yang lebih tinggi).

Begitu pula dalam UU Nomor 23 Tahun 2006 tentang Administrasi Kependudukan Pasal 34 (1) perkawinan yang sah menurut peraturan perundangan wajib dilaporkan oleh penduduk kepada instansi pelaksana di tempat terjadinya perkawinan paling lambat 60 hari sejak tanggal perkawinan. Ayat (2) sebagaimana ayat (1) pejabat pencatatan sipil mencatat pada register akta perkawinan dan menerbitkan kutipan akta perkawinan. Ayat (3) kutipan akta tersebut masing-masing diberikan kepada suami dan istri. Ayat (4) pelaporan sebagaimana ayat (1) bagi penduduk yang beragama Islam dilakukan oleh KUA kecamatan. Ayat (5) data hasil pencatatan wajib disampaikan KUA kecamatan kepada instansi pelaksana dalam waktu paling lambat 10 hari setelah pencatatan perkawinan dilaksanakan. Pasal 36 dalam hal perkawinan tidak dapat dibuktikan dengan akta perkawinan, pencatatan perkawinan dilakukan setelah adanya penetapan pengadilan. UU Nomor 23/2006 tersebut tidak menjadi bagian praktik perkawinan masyarakat Samin Kudus. Tetapi hukum 'adatnya' yang diberlakukan sesuai tradisi leluhurnya.

Pelaksanaan perkawinan yang melanggar UU Perkawinan, tetapi hal tersebut belum pernah terjadi pada masyarakat Samin Kudus sebagaimana tertuang dalam Pasal 8, perkawinan dilarang antara dua orang yang: a) berhubungan darah dalam garis keturunan lurus ke bawah ataupun ke atas; b) berhubungan darah dalam garis keturunan menyamping yaitu antara saudara, antara seorang dengan saudara orang tua dan antara seorang dengan saudara neneknya; c) berhubungan semenda yaitu mertua, anak tiri, menantu dan ibu/bapak tiri; d) berhubungan sesusuan yaitu orang tua sesusuan, anak sesusuan, saudara sesusuan dan bibi/paman sesusuan; dan e) berhubungan saudara dengan isteri atau sebagai bibi atau kemenakan dari isteri, dalam hal seorang suami beristri dari seorang. Sandaran yang membenarkan pelaksanaan perkawinan masyarakat Samin Kudus sebagaimana tertuang dalam UU Nomor 1 Tahun 1974 tentang Perkawinan Pasal 2 (1) perkawinan sah bila dilakukan menurut hukum masing-masing agamanya dan kepercayaannya. Persoalannya Samin mengaku beragama Adam (versi pemerintah dikategorikan aliran kepercayaan). Pasal 6 (1) perkawinan harus didasarkan persetujuan kedua mempelai, Pasal 30 suami-istri memikul kewajiban luhur untuk menegakkan rumah tangga sebagai sendi dasar masyarakat, Pasal 31 (3) suami adalah kepala rumah tangga dan istri adalah ibu rumah tangga.

Paparan di atas, masyarakat Samin Kudus lebih menomorsatukan ajaran nenek moyang, mikul duwur, mendem jero. Kebahagiaan telah mereka miliki dengan taat pada ajaran leluhurnya. Dalam konteks budaya, keunikan tersebut sesuatu yang perlu diuri-uri.

\section{Respon Negara}

Berdasarkan pada pasal 1 (a) Keputusan Menteri Agama RI Nomor 298 Tahun 2003 tentang Pencatatan Nikah bahwa KUA adalah instansi Depag yang bertugas di bidang urusan agama Islam di wilayah kecamatan, di antaranya bertugas melayani dalam hal perkawinan warga yang beragama Islam. Sehingga bagi warga yang nonislam, bukan wilayah kerja KUA Pelayanan perkawinan warga yang beragama Islam di KUA, dilaksanakan oleh Pegawai Pencatat Nikah (PPN). Sebagaimana tertuang dalam Keputusan Menag Nomor 298 Tahun 2003 tentang Pencatatan Nikah Pasal 1 (c), sedangkan Pasal 1 (h) pembantu PPN adalah pemuka agama Islam di desa yang ditunjuk dan diberhentikan oleh Kepala KUA. Karena komunitas Samin beragama Adam, maka perkawinannya bukan wilayah kerja Departemen Agama (KUA). 
Kaitannya dengan tugas Depag dalam bidang penyuluhan agama, KUA Kec. Undaan sangat terbatas personil yang menjangkau pelayanan pada masyarakat beragama, apalagi masyarakat Samin Kudus tidak termasuk satu di antara agama yang disahkan oleh negara karena beragama Adam. Personil KUA Kec. Undaan terdiri seorang kepala, seorang staf administrasi, dua orang penghulu, dan seorang petugas kebersihan.

\section{Eksisnya Perkawinan Model Samin}

Untuk mengetahui faktor eksisnya perkawinan model masyarakat Samin Kudus dapat dipahami batas berlakunya hukum adat, nilai universal hukum adat, sumber hukum adat, akulturasi hukum adat dengan tradisi masa kini. Dalam konteks batas personal, berlakunya ajaran Samin Kudus terbatas pada komunitasnya, sedangkan batas teritorial berlakunya ajaran Samin Kudus hanya di wilayah yang berpenghuni komunitas Samin dengan kehidupan berbasis etika. Kondisi Samin Kudus dalam berinteraksi antara ajarannya (adat) dengan kondisi masa kini tercermin dalam ketaatan terhadap peraturan pemerintah dan tiga perubahan dalam hal pekerjaan, pendidikan, dan pakaian.

\section{Simpulan dan Saran Simpulan}

Prinsip pernikahan Samin karena anak (calon kedua mempelai) mempunyai orang tua, orang tua (ibu) berkewajiban merukunkan anak, sedangkan orang tua (bapak) berkewajiban menyetujui anak dalam melaksanakan pernikahan, sehingga yang berkewajiban dan berhak menikahkan adalah orang tuanya sendiri. Meskipun demikian, masyarakat Samin pernah melibatkan peran negara (kepala desa) dalam perkawinan di era Orba diminta menyaksikan perkawinan dengan menghadiri ke rumah kepala desa (petinggi). Tetapi -karena anggapannya- kepala desa masa kini tidak sebagaimana kepala desa masa lalu dalam hal pelimpahan kekuasaan, yang dulu kekuasaan sepenuhnya oleh kepala desa, sekarang ini kekuasaan di tangan warga. Sehingga sekarang ini masyarakat Samin melibatkan warga Samin dan nonsamin untuk diundang menyaksikan prosesi perkawinannya di rumahnya. Kedudukan tokoh (botoh) Samin dalam prosesi perkawinan sebagai pemberi wejangan, sesorah (doa) bagi kemanten dan keluarganya agar memperoleh kesuksesan hidup. Sedangkan keberadaan kedua orang tua kemanten adalah merestui dan melaksanakan niat kemanten dalam proses perkawinan.

Proses perkawinan masyarakat Samin mulai dari ngendek, nyumuk, paseksen, nyuwito, lan kondo, tidak selalu pakem dilaksanakan secara urut. Karena peneliti menemukan satu perkawinan Samin Kudus yang tanpa melalui proses ngendek sebagaimana dilakukan pasangan Agus Gunawan (putra Bpk. Wargono, Ibu Niti Rahayu) dengan Anita (Putri Bpk. Suwito) keduanya warga Dukuh Kaliyoso, Desa Karangrowo, Kecamatan Undaan, Kudus karena sebelum dilaksanakan perkawinan, keduanya sama-sama telah ngendek calon masing-masing, tetapi karena proses ngendek keduanya dengan (calon) pasangannya masing-masing dalam usia balita, sehingga ketika dewasa keduanya menemukan tambatan hati sesuai pilihan hatinya. Perkawinan masyarakat Samin Kudus pun tidak selalu dengan masyarakat Samin (sealiran), tetapi di antara mereka ada yang mendapatkan pasangan hidup dari nonsamin atau dari pemeluk ajaran Samin sendiri. Ada kalanya masyarakat Samin meninggalkan ajaran Samin karena menikah dengan orang nonsamin, ada juga orang nonsamin menikah dengan orang Samin keduanya menjadi Samin. Ada juga perkawinan antarsamin tetapi anak turunnya menjadi nonsamin. Meskipun masyarakat Samin menemukan jodohnya mayoritas dengan sesama Samin, juga terjadi perceraian yang dialami Ibu Masini (warga Samin dari Dukuh Kaliyoso, Desa Karangrowo, Kecamatan Undaan, Kabupaten Kudus, Jateng) dengan Bpk. Suwarjo (warga Samin dari Desa Bombong, Kecamatan Sukolilo, Kabupaten Pati) dan Bpk. Sulasno (asal Dukuh Kaliyoso, Desa Karangrowo, Kecamatan Undaan, Kudus, Jateng) dengan Ibu Wiji (asal Desa Bombong, Kecamatan Sukolilo, Kabupaten Pati, Jateng).

Adapun strata usia masyarakat Samin terpilah adam timur, adam brahi, dan wong sikep kukuh wali adam. Adam timur adalah generasi Samin yang belum dewasa, belum memiliki 'rasa' dengan lain jenis. Sedangkan adam brahi adalah generasi Samin yang telah dewasa dan memiliki 'rasa' terhadap lawan jenis sehingga siap dan sanggup 
menikah. Penjenjangan usia tersebut tidak menggunakan penanggalan atau usia (penahunan). Adapun wong sikep kukuh wali Adam adalah orang Samin yang telah berkeluarga. Prosesi pernikahan masyarakat Kudus nonsamin pada umumnya terdapat perbedaan. Kokohnya masyarakat Samin Kudus melaksanakan perkawinan adat karena keberadaan tokoh dan orangtua Samin masih eksis dijadikan tauladan hidup bagi generasinya dalam nguri-uri budaya dan ajaran leluhurnya, Ki Samin Surosentiko. Kedudukan tokoh adalah sebagai bapak dan pemimpin. Peran bapak diharapkan menyelesaikan permasalahan, memberi petunjuk, dan nasehat. Adapun peran pemimpin sebagai pendamai jika komunitas adatnya diganggu komunitas lain. Hal tersebut dapat dilaksanakan dengan baik oleh botohnya (tokoh adatnya). Bermodalkan etika sosial yang santun, komunitas Samin Kudus ketika melaksanakan perkawinan yang tidak menyertakan peran negara (KUA atau catatan sipil) pun tidak direspon negatif oleh lingkungannya yang nonsamin. Dalam kaca pandang birokrasi, bahwa KUA adalah birokrat pemerintah pada level kecamatan yang bertugas di antaranya memfasilitasi perkawinan komunitas muslim. Karena komunitas Samin pemeluk agama Adam, berarti bukan wilayah kerja KUA. Bagi tokoh agama (Islam) di Kudus tidak respon negatif dengan perkawinan Samin karena hubungan kemanusiaan keduanya responsif dan permisif dalam hal praktik beragama.

Dengan deskripsi tersebut, menegaskan bahwa penelitian ini mendedahkan eksisnya model perkawinan yang tidak selalu taat produk hukum positif, hanya mengandalkan patuh pada ajaran leluhurnya, selain dukungan dari komunitas nonsamin imbas bekal perilaku sosial Samin yang humanis dan responsif terhadap kebijakan pemerintah, seperti membayar pajak, menjadi Ketua RW dan RT. Pemerintah pun (KUA) tidak dapat berbuat karena keterbatasan perangkat dukung (SDM) dan budaya birokrat yang lentur karena komunitas Samin tidak memicu konflik vertikal maupun horisontal.

\section{Saran}

Beragama yang terletak dalam hati dan teraplikasikan dalam perilaku sosial pada dasarnya wilayah diri yang perlu dilindungi oleh publik dan negara. Perilaku beragama dalam hal ini perkawinan Samin Kudus pun perlu diposisikan sebagai wilayah diri (Samin) yang tidak idial jika dikoyak kenyamanannya, terutama aspek HAM. Perkawinan Samin juga memenuhi kaidah perundangan berupa adanya wali (orangtua), saksi (tamu undangan dan keluarga), adanya kedua mempelai, adanya ijab-kabul, mahar (yang tidak dinyatakan secara terbuka di hadapan forum nyuwito), dan sekufu (seagama). Tidak disertakannya peran negara (KUA atau Kantor Catatan Sipil) karena dalih bahwa Nabi Adam AS ketika kawin dengan Hajar pun tidak menyertakan 'catatan tertulis' (baca: surat nikah), sebagai esensi dasar pijakan dalam ajaran leluhurnya. Samin lebih mementingkan kenyamanan dan ketentraman dalam berkeluarga dan berinteraksi sosial dengan lingkungan dan pemerintah RI, tidak mempersoalkan 'surat'. Selama ini, argumen pentingnya surat nikah (produk KUA atau Kantor Catatan Sipil) sebagai bentuk antisipasi negara dalam memfasilitasi warganya jika terjadi persengketaan. Dengan pencatatan nikah versi pemerintah agar mendapatkan kepastian hukum.

Bagi masyarakat Samin, kepastian hukum diwujudkan dengan realisasi prinsip kesaminan dalam berperilaku, termasuk dalam perkawinan. Jika terjadi persengketaan keluarga, menyangkut perceraian dan pembagian harta warisan, cukup diselesaikan secara kekeluargaan dengan prinsip saling memahami dan menyadari. Hal ini didukung data yang telah diperoleh penulis, tidak ditemukan konflik perceraian dan pembagian harta warisan, apalagi bagi suami atau isteri nikah lagi dengan cara berbohong dengan statusnya yang telah nikah, tetapi mengaku belum nikah. Semua itu merupakan pesan moral bagi publik yang selalu mendewa-dewakan formalitas, kadangkala menafikan realitas kehidupan yang etis. Sebagaimana digambarkan warisan leluhurnya, Ki Samin, sebagai esensi Samin utuh yakni berprinsip untuk tidak drengki (membuat fitnah), srei (serakah), panasten (mudah tersinggung), dawen (mendakwa tanpa bukti), kemeren (iri hati), nyiyo marang sepodo (berbuat nista), dan bejok reyot iku sedulure yen gelem dindaku dulur (mengaku siapapun sebagai saudara). Sekaligus berpantangan dalam bedok (menuduh), colong 
(mencuri), pethil (mengambil barang yang masih menyatu dengan alam, seperti padi di sawah), jumput (mengambil barang yang tidak menyatu dengan alam, seperti beras), dan nemu (menemukan). Meskipun, warga Samin adalah manusia yang dibekali oleh Tuhannya (Yai) berupa akal dan nafsu, sehingga berpeluang menjadi orang yang taat prinsip atau tidak taat prinsip Samin. Semua itu adalah diri pribadi masingmasing sebagai dewan jurinya.

\section{Pustaka Acuan}

Atho' Mudzhar. 1998. Pendekatan Studi Islam dalam Teori dan Metode. Pustaka Pelajar: Yogyakarta. Barbara Tedlock. 2000. Ethnography and Ethnographic Representation dalam Hand Book of Qualitative Research second edition. Norman K. Denzin and Y.S Lincoln (ed). Sage Publication, Inc. New Delhi.

Endraswara. 2006. Metode, Teori, Teknik Penelitian Kebudayaan. Pustaka Widyatama: Sleman. Irwan Abdullah. 1999. Rekonstruksi dan Reproduksi Budaya. Pustaka Pelajar: Yogyakarta. Kompilasi Hukum Islam. 2007. Fokusmedia: Bandung. Keputusan Menteri Agama Nomor 298/2003 tentang Pencatatan Nikah. Muhadjir, Noeng. 1996. Metodologi Penelitian Kualitatif. Rakesarasin: Bandung. . 2007. Madzhab-Madzhab Antropologi. LkiS: Yogyakarta.

Maryaeni. 2005. Metode Penelitian Kebudayaan. Bumi Aksara: Jakarta.

PP No. 55 Tahun 2007 tentang Pendidikan Agama dan Pendidikan Keagamaan

Robert C. Bogdan. 1982. Methodology Qualitative Research. London University Press: Ltd. Publishing. Spradley, James P. 1997. Metode Etnografi. Tiara Wacana: Yogyakarta.

Shafra. 2006. Nikah Gratis Analisis tentang Ba'ah dalam Perkawinan. Jurnal Hukum Islam Al-Hurriyah. Vol.7 No.2 2006. STAIN Bukittinggi.

Suchamdi, Maulana, dan Rifki. 2007. Ketentuan Wali Nikah dan Poligami dalam Hukum Keluarga Negara Muslim Modern. Kodifikasia, Jurnal Penelitian Keagamaan dan Sosial-Budaya. Vol.01 nomor 01.STAIN Ponorogo.

Sudjarwo. 2001. Metodologi Penelitian Sosial. Bumi Aksara: Jakarta.

Suprayogo, Imam dan Tobroni. 2001. Metodologi Penelitian Sosial-Agama.Rosda: Bandung.

Sudikan, Setya Yuwana. 2001. Metode Penelitian Kebudayaan. Citra Wacana: Surabaya.

Suwardi Endraswara. 2006. Metode, Teori, Teknik Penelitian Kebudayaan. Pustaka Widyatama: Sleman. Syafiin Mansur. 2006. Poligami dalam Agama Samawi. Alqalam. Jurnal Ilmiah bidang Keagamaan dan Masyarakat. Vol.23 no.1. IAIN Sultan Maulana Hasanuddin, Serang, Banten.

Syam, Nur. 2005. Islam Pesisir. LKiS: Yogyakarta.

Syam, Nur. 2007. Madzhab-Madzhab Antropologi. LKiS: Yogyakarta.

Samuel Octora. Mungkinkah Belis Disederhanakan? Harian Kompas, 21 Juli 2006.

Trianto dan Titik Triwulan. 2008. Perkawinan Adat Wologoro Suku Tengger. Prestasi Pustaka. Jakarta.

Undang-Undang Nomor 1 Tahun 1974 tentang Perkawinan.

Undang-Undang Nomor 23 Tahun 2006 tentang Administrasi Kependudukan.

Zakaria Syafi'i. 2007. Kontroversi Hukum Perkawinan Berbeda Agama. Jurnal Alqalam. vol. 24 no.1. IAIN Sultan Hasanuddin, serang, Banten. 